\title{
ANALISIS POTENSI KEBANGKRUTAN PT. BERLIAN LAJU TANKER, Tbk. DENGAN MENGGUNAKAN ALTMAN'S Z SCORE
}

\author{
Iswandi \\ Accounting Department, Faculty of Economic and Communication, BINUS University \\ Jln. K.H. Syahdan No. 9, Palmerah, Jakarta Barat 11480 \\ iswandi@binus.ac.id
}

\begin{abstract}
PT. Berlian Laju Tanker, Tbk. (BLTA) is a company engaged in the ocean transportation services listed on the Indonesia Stock Exchange and the Singapore Stock Exchange. In 2009 and 2010 BLTA experienced a net loss. At the end of 2011 the company rocked the financial markets in Indonesia and Singapore being unable to meet financial obligations to financial institutions and corporate bondholders. Given such conditions until the end of August 2012 BLTA can not submit audited financial statement of year 2011 to the authorities of stock exchange and public. By using the 2007 to 2010 audited financial statements and June 2011 inhouse financial statement were analyzed using Altman's Z score model can be known that since 2007 BLTA produce a Z score were classified bankruptcy. Investors should analyze the financial condition by using Z Score in order to minimized shareholders and bondholders potential losses.
\end{abstract}

Keywords: Altman's Z score model, failure, insolvency, default, bankruptcy

\begin{abstract}
ABSTRAK
PT Berlian Laju Tanker, Tbk (BLTA) adalah perusahaan yang bergerak di bidang jasa transportasi laut yang terdaftar di Bursa Efek Indonesia dan Bursa Efek Singapura. Pada tahun 2009 dan 2010 posisi keuangan BLTA menunjukkan kerugian bersih. Pada akhir tahun 2011 perusahaan mengejutkan pasar keuangan di Indonesia dan Singapura tidak mampu memenuhi kewajiban keuangan kepada lembaga keuangan dan pemegang obligasi korporasi. Mengingat kondisi tersebut sampai akhir Agustus 2012 BLTA tidak dapat menyampaikan laporan keuangan yang telah diaudit tahun 2011 untuk otoritas bursa dan publik. Dengan menggunakan laporan keuangan 2007-2010 yang diaudit dan juga laporan Juni 2011 yang telah dianalisis dengan menggunakan Model Altman Z score dapat diketahui bahwa sejak tahun 2007 BLTA berdasarkan klasifikasi tersebut dapat dinyatakan bangkrut. Investor harus menganalisis kondisi keuangan dengan menggunakan Z Skor untuk meminimalisasi kerugian pemegang saham dan pemegang obligasi
\end{abstract}

Kata kunci: Altman's Z score model, failure, insolvency, default, bankruptcy 


\section{PENDAHULUAN}

Kegiatan usaha memiliki potensi untuk berhasil dan mengalami kegagalan yang disebabkan oleh mismanajemen atau makro ekonomi atau ketidakmampuan manajemen perusahaan dalam memenangkan persaingan usaha. Menurut Altman (1993), ketidaksuksesan kegiatan usaha perusahaan dapat dikelompokkan menjadi failure, insolvency, default dan bankruptcy. Failure apabila realisasi Return On Investment (ROI) secara signikan lebih rendah dari ROI investasi yang sejenis. Insolvency terjadi apabila perusahaan memiliki kinerja negatif, yaitu apabila perusahaan tidak dapat memenuhi kewajiban jangka pendek karena kesulitan likuiditas yang bersifat sementara atau kronis. Default bisa secara teknis dan atau legal, karena perusahaan tidak memenuhi perjanjian dengan kreditur yang memberikan dampak kreditur dapat melakukan tindakan hukum kepada perusahaan. Sedangkan bankruptcy, salah satu tipenya sesuai dengan penjelasan diatas dan merefer juga kepada nilai total networth perusahaan. Tipe yang lain adalah apabila perusahaan secara formal mengumumkan kebangkrutannya melalui pengadilan atau lembaga berwenang lainnya, yang diikuti dengan likuidasi aset atau mengikuti program penyelamatan/penyehatan.

PT. Berlian Laju Tanker (BLTA) semula bernama PT. Bhaita Laju Tanker merupakan sebuah perusahaan publik yang bergerak di bidang jasa angkutan laut yang didirikan pada tahun 1981. Fokus kegiatan bisnis BLTA adalah pengangkutan produk-produk cair seperti chemical, oil \& gas dan edible oil di wilayah Asia, Timur Tengah, Eropa, Amerika Selatan dan Amerika Utara serta menyewakan kapal-kapal kepada pihak ketiga melalui perjanjian. Sampai dengan Juni 2011 BLTA memiliki 40 unit kapal tanker kimia dengan total kapasitas 601.003 DWT, 11 unit kapal tanker minyak dengan total kapasitas 748.873 DWT, 15 unit kapal tanker gas dengan total kapasitas 146.224 DWT, 1 unit kapal tanker FPSO kapasitas 60.874 DWT dan 27 unit kapal carter dengan total kapasitas 691.914 DWT.

PT. Berlian Laju Tanker, Tbk tercatat di Bursa Efek Indonesia (BEI) sejak tanggal 26 Maret 1990 dengan kode BLTA.JK dan sejak tanggal 22 September 2006 tercatat di Singapore Stock Exchange (SGX) dengan kode PTBL.SJ. BLTA merupakan perusahaan Indonesia pertama yang melakukan pencatatan saham di BEI dan SGX (dual listed). adalah sbb:

Berdasarkan laporan keuangan inhouse per 30 Juni 2012, susunan pemegang saham BLTA

Tabel 1 Susunan Pemegang Saham BLTA

\begin{tabular}{|l|r|r|}
\hline \multicolumn{1}{|c|}{ Pemegang Saham } & \multicolumn{1}{c|}{ Nilai (USD) } & \multicolumn{1}{c|}{ \% tase } \\
\hline PT. Tunggaladhi Baskara & 41.583 .000 & 37,95 \\
Tuan Widihardja Tanudjaja & 25.000 & 0,02 \\
Koperasi Karyawan Berlian & 23.000 & 0,02 \\
Siana Anggraeni Surya & 1.000 & 0,00 \\
Masyarakat (dibawah 5\%) & 67.943 .000 & 62,01 \\
\hline Jumlah & $\mathbf{1 0 9 . 5 7 5 . 0 0 0}$ & $\mathbf{1 0 0 , 0 0}$ \\
\hline
\end{tabular}

Pada pertengahan tahun 2011, BLTA mengejutkan pasar modal di Indonesia dan Singapura karena ketidakmampuan BLTA memenuhi kewajiban-kewajiban keuangannya, baik kewajiban kredit kepada bank/lembaga keuangan, maupun kewajiban kepada pemegang obligasi. Berdasarkan laporan keuangan inhouse per 30 Juni 2011, BLTA memiliki kewajiban kepada kreditur bank/lembaga keuangan sebesar ekuivalen 1,655.49 juta dolar Amerika dan pemegang obligasi sebesar ekuivalen 132.57 juta dolar Amerika dengan rincian sebagai berikut: 
Tabel 2 Hutang Bank dan Lembaga Keuangan

\begin{tabular}{|l|r|r|}
\hline \multicolumn{1}{|c|}{} & \multicolumn{1}{c|}{ (USD 000) } \\
\hline Hutang Bank dan Lembaga Keuangan & 31-Des-10 & 30-Jun-11 \\
\hline Hutang Jangka Pendek & 14.459 & 15.122 \\
\hline Hutang Jangka Panjang & 1.594 .182 & 1.640 .376 \\
\hline Jumlah & $\mathbf{1 . 6 0 8 . 6 4 1}$ & $\mathbf{1 . 6 5 5 . 4 9 8}$ \\
\hline
\end{tabular}

Tabel 3 Obligasi

\begin{tabular}{|l|l|r|r|r|}
\hline \multicolumn{1}{|c|}{ Obligasi } & \multicolumn{1}{|c|}{ Keterangan } & $\begin{array}{c}\text { Rating Juli } \\
\text { 201l }\end{array}$ & 31-Des-10 & 30-Jun-11 \\
\hline Obligasi BLTA III & terbit 5 Juli 2007, jatuh tempo 5 Juli 2012, nominal IDR 700 milyar & idA- (Pefindo) & 77.820 & 81.424 \\
\hline Obligasi BLTA IV & terbit 29 Mei 2009, jatuh tempo 28 Mei 2011, 2012, 2014, nominal IDR 400 milyar & idA- (Pefindo) & 37.813 & 39.549 \\
\hline Sukuk Ijarah I & terbit 5 Juli 2007, jatuh tempo 5 Juli 2012, nominal IDR 200 milyar & idA- (Pefindo) & 22.234 & 23.264 \\
\hline Sukuk Ijarah II & terbit 29 Mei 2009, jatuh tempo 28 Mei 2012, 2014, nominal IDR 100 milyar & idA- (Pefindo) & 11.122 & 11.632 \\
\hline Diskonto belum diamortisir & terbit 5 Juli 2007, jatuh tempo 5 Juli 2012, nominal IDR 700 milyar & & $(728)$ & $(614)$ \\
\hline CPLTD & terbit 5 Juli 2007, jatuh tempo 5 Juli 2012, nominal IDR 700 milyar & & - & 22.682 \\
\hline Hutang Obligasi Bersih & & & $\mathbf{1 4 8 . 2 6 1}$ & $\mathbf{1 3 2 . 5 7 3}$ \\
\hline
\end{tabular}

Besar kemungkinan keterkejutan tersebut karena investor kurang waspada terhadap early warning signal yang ada. Salah satu indikatornya adalah rating untuk obligasi BLTA masih dikelompokkan sebagai investment grade, sesuai tabel berikut:

Tabel 4 Rating Obligasi BLTA

\begin{tabular}{|l|c|l|l|l|c|}
\hline \multicolumn{1}{|c|}{ Obligasi } & $\begin{array}{c}\text { Rating 03-05-2007 } \\
\text { s/d 01-06-2008 }\end{array}$ & $\begin{array}{c}\text { Rating 06-11-2008 s/d } \\
\text { 01-06-2009 }\end{array}$ & $\begin{array}{c}\text { Rating 13-04-2009 } \\
\text { s/d 01-05-2010 }\end{array}$ & $\begin{array}{c}\text { Rating 14-05-2010 } \\
\text { s/d 01-05-2011 }\end{array}$ & $\begin{array}{c}\text { Rating 20-07-2011 s/d } \\
\text { 01-05-2012 }\end{array}$ \\
\hline Obligasi BLTA III & id AA- (outlook stable) & id A+ (outlook negative) & id A (outlook stable) & id A- (outlook stable) & id A- (outlook negative) \\
\hline Obligasi BLTA IV & id AA- (outlook stable) & id A+ (outlook negative) & id A (outlook stable) & id A- (outlook stable) & id A- (outlook negative) \\
\hline Sukuk ljarah I & id AA- (outlook stable) & id A+ (outlook negative) & id A (outlook stable) & id A- (outlook stable) & id A- (outlook negative) \\
\hline Sukuk ljarah II & id AA- (outlook stable) & id A+ (outlook negative) & id A (outlook stable) & id A- (outlook stable) & id A- (outlook negative) \\
\hline
\end{tabular}

Pefindo menurunkan rating BLTA dari idA menjadi idBBB pada rilis tanggal 17 Januari 2012 dan ditempatkan pada kategori creditwatch dengan implikasi negatif. Berdasarkan rilis tanggal 26 Januari 2012, Pefindo kemudian menurunkan rating obligasi BLTA menjadi idCCC pada tanggal 26 Januari 2012 dan selanjutnya menjadi idD (default) pada tanggal 28 Februari 2012.

Berdasarkan rilis BLTA tanggal 27 Februari 2012, secara resmi BLTA mengumumkan default instrumen hutang dan perusahaan tidak melakukan pembayaran untuk instrumen hutang sebagai berikut: 
Tabel 5 Default Instrumen Hutang

\begin{tabular}{|c|c|c|c|c|}
\hline No & Peminjam & Instrumen Hutang & Nilai (USD) & Jatuh Tempo \\
\hline 1 & BLT Finance B.V & Obligasi Konversi & $36,632,940$ & 09-02-2012 \\
\hline 2 & BLT International Co & Obligasi Konversi & $7,500,000$ & 09-02-2012 \\
\hline 3 & Berlian Laju Tanker & Obligasi BLT IV/2009 seri B & IDR 5.812 .500 .000 & 27-02-2012 \\
\hline 4 & Berlian Laju Tanker & Obligasi BLT IV/2009 seri C & IDR 7.718.750.000 & 27-02-2012 \\
\hline 5 & Berlian Laju Tanker & Sukuk Ijarah BLT II/2009 seri A & IDR 1.743 .750 .000 & 27-02-2012 \\
\hline 6 & Berlian Laju Tanker & Sukuk Ijarah BLT II/2009 seri B & IDR 2.234.375.000 & 27-02-2012 \\
\hline
\end{tabular}

Altman telah mengembangkan model-model dalam evaluasi kebangkrutan perusahaan yang dikenal dengan Z Score sejak tahun 1968, yang terus dikembangkan untuk industri manufaktur (Z') dan industri non manufaktur (Z”). Menurut Altman (1993) Z score model adalah analisa linear dari 5 alat ukur yang dijumlahkan sehingga menghasilkan nilai keseluruhan sebagai dasar untuk mengklasifikasikan perusahaan dalam kelompok tertentu, dengan fungsi diskriminan:

$Z=1,2 X_{1}+1,4 X_{2}+3,3 X_{3}+0,6 X_{4}+1,0 X_{5}$

dengan cutt off:

Z Sore $<1,81$ diklasifikasikan bangkrut

$1,81 \mathrm{~s} / \mathrm{d} 2,99$ diklasifikasikan abu-abu (gray area)

Z Sore $>$ 2,99 diklasifikasikan tidak bangkrut

Penjelasan:

$\mathrm{X}_{1}$, Working Capital/Total Assets (WC/TA)

Working capital adalah selisih antara current asset dan current liabilities. Lazimnya, perusahaan yang mengalami kerugian operasi (operating loss) akan mengalami penurunan current asset.

$\mathrm{X}_{2}$, Retained Earnings/Total Assets (RE/TA)

Retained earning menunjukkan saldo earning yang diinvestasikan dan atau kerugian yang diperoleh sepanjang usia perusahaan.

$\mathrm{X}_{3}$, Earnings Before Interest and Taxes/Total Assets (EBIT/TA)

Rasio ini menggambarkan produktivitas aset perusahaan yang dipisahkan dari faktor pajak atau hutang. Insolvency dalam kebangkrutan terjadi ketika total liabilities melebihi fair value asset perusahaan yang nilainya ditentukan oleh earning power aset.

$\mathrm{X}_{4}$, Market Value of Equity/Book Value of Total Liabilities (MVE/TL)

Equity diukur dari kombinasi market value seluruh saham baik ordinary share dan preferred share. Sedangkan liabilities terdiri dari current liabilities dan long term liabilities. Ukuran tersebut menggambarkan berapa besar penurunan nilai asset perusahaan sebelum liabilities melebihi asset atau perusahaan menjadi insolvent.

$\mathrm{X}_{5}$, Sales/Total Assets (S/TA)

Rasio capital turn over menggambarkan kemampuan aset perusahaan dalam optimalisasi penjualan. Ukuran tersebut juga menggambarkan kemampuan manajemen dalam menjalankan usaha dalam kondisi kompetisi yang ketat. 
Berikut adalah beberapa variasi dari Altman's Z Score (White, 2003) yaitu untuk perusahaan swasta/manufaktur (Z') dan untuk perusahaan jasa (Z”), dimana:

$Z^{\prime}=0,717 X_{1}+0,847 X_{2}+3,107 X_{3}+0,420 X_{4}+0,998 X_{5}$

dengan cutt off :

Z Sore $<1,23$ diklasifikasikan bangkrut

$1,23 \mathrm{~s} / \mathrm{d} 2,90$ diklasifikasikan abu-abu (gray area)

Z Sore $>2,90$ diklasifikasikan tidak bangkrut

Dan

$$
\text { Z" = 6,56 } X_{1}+3,26 X_{2}+6,72 X_{3}+1,05 X_{4}
$$

dengan cutt off :

Z Sore $<1,10$ diklasifikasikan bangkrut

1,10 s/d 2,60 diklasifikasikan abu-abu (gray area)

Z Sore $>$ 2,60 diklasifikasikan tidak bangkrut

Berdasarkan penelitian yang dilakukan Altman menggunakan model tersebut di atas, dengan menggunakan sampel 25 sampai dengan 33 perusahaan, diketahui bahwa model tersebut akurat dalam memprediksi potensi kebangkrutan perusahaan, dengan tingkat akurasi sebagai berikut (Altman 1993):

Tabel 6 Prediksi Potensi Kebangkrutan Perusahaan

\begin{tabular}{ccc}
\hline Tahun sebelum Failure & Sampel perusahaan & Akurasi \\
\hline 1 & 33 & $95 \%$ \\
2 & 32 & $72 \%$ \\
3 & 29 & $48 \%$ \\
4 & 28 & $29 \%$ \\
5 & 25 & $36 \%$ \\
\hline
\end{tabular}

\section{METODE}

Metode penelitian adalah studi kepustakaan, dengan menggunakan data sekunder berupa laporan keuangan BLTA dan informasi rating dari situs PT. Perusahaan Efek Indonesia (http://www.new.pefindo.com), menggunakan Altman's Z Score Model dengan rumus-rumus sebagai berikut.

Menggunakan versi awal Z Score model, yaitu:

$$
\begin{aligned}
& Z=1,2 X_{1}+1,4 X_{2}+3,3 X_{3}+0,6 X_{4}+1,0 X_{5} \\
& Z^{\prime}=0,717 X_{1}+0,847 X_{2}+3,107 X_{3}+0,420 X_{4}+0,998 X_{5}
\end{aligned}
$$

Mengingat BLTA merupakan perusahaan jasa angkutan laut, maka digunakan Z Score model untuk perusahaan jasa, yaitu:

$$
\text { Z” }=6,56 X_{1}+3,26 X_{2}+6,72 X_{3}+1,05 X_{4}
$$


Tujuan penelitian adalah untuk mengetahui apakah potensi kebangkrutan BLTA atau kesulitan perusahaan untuk memenuhi kewajiban keuangannya kepada kreditur dan pemegang obligasi dapat diprediksi atau dideteksi lebih awal dengan menggunakan model Z Score sesuai rumus tersebut di atas. Untuk mendukung evaluasi tersebut juga dilakukan evaluasi kondisi keuangan BLTA selama periode penelitian untuk mengetahui faktor-faktor yang mempengaruhi nilai Z Score.

\section{HASIL DAN PEMBAHASAN}

\section{Evaluasi Laporan Keuangan Konsolidasi BLTA per 31 Desember 2007 s/d per 30 Juni 2011}

Data yang digunakan dalam penelitian ini adalah laporan keuangan audit konsolidasi BLTA tahun 2007 sampai dengan tahun 2010 dan laporan keuangan inhouse per 30 Juni 2011. Penelitian tidak menggunakan laporan keuangan audit tahun 2011 karena sampai dengan saat ini (Agustus 2012) laporan tersebut belum tersedia di situs Bursa Efek Indonesia (www.idx.co.id) dan situs BLTA (www.blt.co.id). Terinformasi bahwa BLTA belum menerbitkan laporan keuangan audit tahun 2011 maupun laporan keuangan inhouse triwulan I dan triwulan II tahun 2012. Berdasarkan surat BLTA No. 053/BLT/CS/BPM/VI/12 tanggal 4 Juni 2012 kepada Bapepam LK, BLTA menjelaskan bahwa keterlambatan (waiver) penyampaian laporan keuangan audit tahun 2011 telah disetujui oleh SGX.

Kondisi keuangan BLTA selama 5 (lima) tahun terakhir adalah sebagai berikut:

Tabel 7 Kondisi Keuangan BLTA 5 Tahun Terakhir

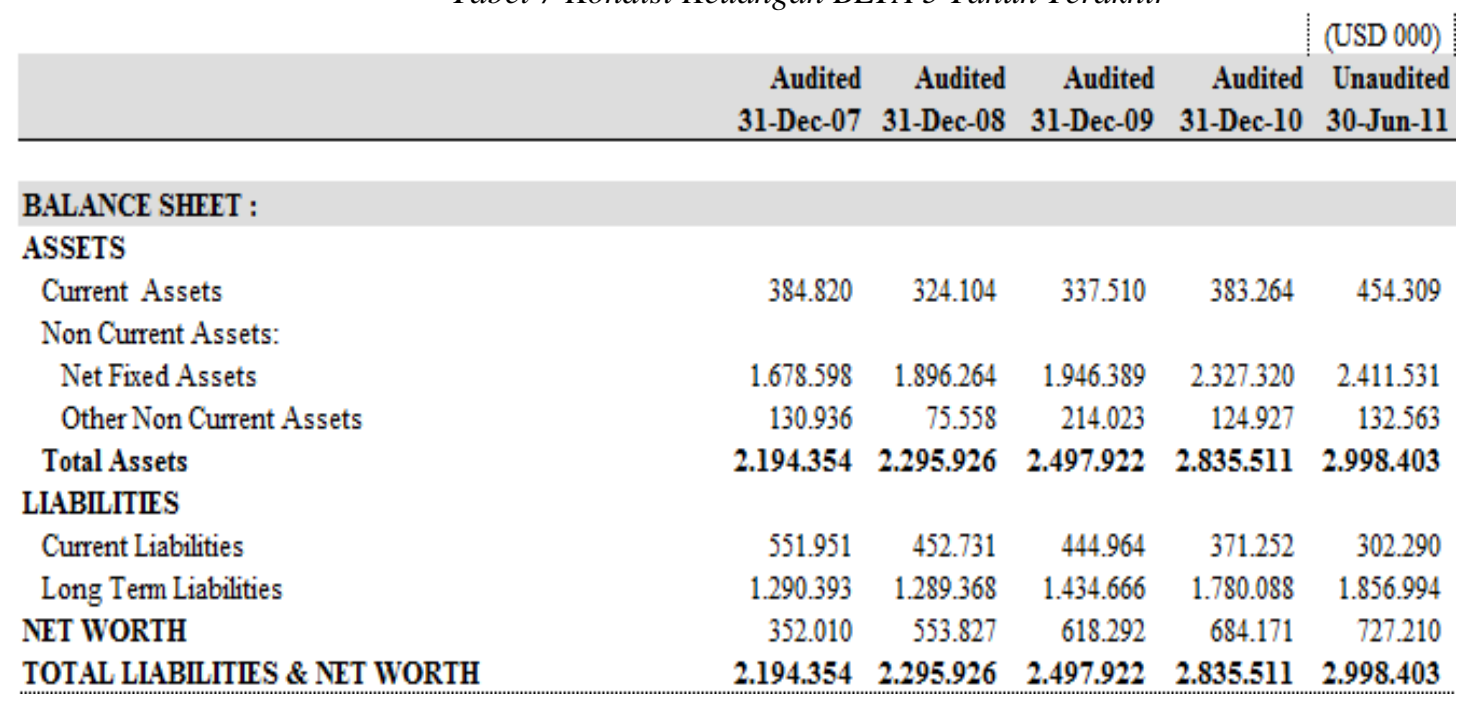

Dari resume neraca konsolidasian tersbut diatas, dapat diketahui bahwa bagian terbesar dari current asset adalah piutang usaha dan kas/deposito. Aset BLTA meningkat terutama dari peningkatan fixed asset yang didanai dari long term liabilities khususnya dari hutang bank dan penerbitan obligasi. Selain itu, BLTA cenderung menggunakan hutang untuk membiayai kegiatan operasinya.

Meskipun mengalami net loss pada tahun 2009 dan 2010 namun tren net worth meningkat yang berasal dari agio saham (additional paid in capital) atas penawaran terbatas saham IV dan V serta surplus revaluasi yang berasal dari revaluasi seluruh kapal, apabila kapal yang telah direvaluasi dijual, bagian dari surplus tersebut direalisasikan dengan memindahkan langsung ke saldo laba. 
Tabel 8 Resume Laba-Rugi PT. BLTA TBK.

\begin{tabular}{|c|c|c|c|c|c|}
\hline & & & & & (USD 000) \\
\hline & $\begin{array}{r}\text { Audited } \\
\text { 31-Dec-07 }\end{array}$ & $\begin{array}{r}\text { Audited } \\
\text { 31-Dec-08 }\end{array}$ & $\begin{array}{r}\text { Audited } \\
\text { 31-Dec-09 }\end{array}$ & $\begin{array}{r}\text { Audited } \\
\text { 31-Dec-10 }\end{array}$ & $\begin{array}{c}\text { Unaudited } \\
\text { 30-Jun-11 }\end{array}$ \\
\hline INCOME STATEMENT : & & & & & \\
\hline Operating Revenues & 386,641 & 723,682 & 618,346 & 656,854 & 323,111 \\
\hline Direct Cost & 212,019 & 390,988 & 351,923 & 416,818 & 203,015 \\
\hline Direct Cost/Sales & $54.84 \%$ & $54.03 \%$ & $56.91 \%$ & $63.46 \%$ & $62.83 \%$ \\
\hline Gross Profit & 174,622 & 332,694 & 266,423 & 240,036 & 120,096 \\
\hline Sales, General \& Adm Expenses & 24,540 & 35,534 & 31,584 & 32,371 & 13,368 \\
\hline SGA/Sales & $6.35 \%$ & $4.91 \%$ & $5.11 \%$ & $4.93 \%$ & $4.14 \%$ \\
\hline Operating Profit (EBITDA) & 150,083 & 297,160 & 234,839 & 207,665 & 106,728 \\
\hline Depr \& Amort Exp & 54,736 & 103,847 & 134,932 & 146,485 & 67,240 \\
\hline Other (Income) Expense & $(52,238)$ & $(143,298)$ & 275,322 & 76,074 & $(63,526)$ \\
\hline Extra Ordinary Items & $(2,888)$ & $(94,989)$ & (762) & 2,901 & 599 \\
\hline EBIT & 147,585 & 336,611 & $(175,415)$ & $(14,894)$ & 103,014 \\
\hline Interest Expense & 66,039 & 117,231 & 109,500 & 138,322 & 79,703 \\
\hline EBT & 81,546 & 219,380 & $(284,915)$ & $(153,216)$ & 23,311 \\
\hline Income Tax & 966 & 1,016 & 961 & 1,185 & 804 \\
\hline EAT (Net Income) & 80,580 & 218,364 & $(285,876)$ & $(154,401)$ & 22,507 \\
\hline Net Profit Margin $(\%)$ & $20.84 \%$ & $30.17 \%$ & $-46.23 \%$ & $-23.51 \%$ & $6.97 \%$ \\
\hline Earning Per Share (Basic) (USD/lembar) & 0.0211 & 0.0457 & $(0.0559)$ & $(0.0173)$ & 0,0019 \\
\hline
\end{tabular}

Dari resume laba-rugi konsolidasian tersebut di atas, dapat diketahui bahwa pendapatan BLTA meningkat pesat pada tahun 2008 karena peningkatan penerimaan jasa angkutan kapal sebesar 79,2\% sejalan dengan tambahan 14 unit kapal milik perusahaan di tahun 2008, sehingga menyebabkan net income mencapai 30,17\%. Namun, realisasi pendapatan tahun 2009 dan 2010 mengalami penurunan karena dampak dari krisis keuangan global sehingga volume angkutan dan tarif angkutan mengalami penurunan dan belum kembali ke tarif sebelum krisis.

Penurunan pendapatan terutama disebabkan oleh krisis ekonomi dunia yang berdampak pada melemahnya produksi dan konsumsi minyak dunia. Kondisi ini memiliki pengaruh yang cukup signifikan bagi BLTA karena sebagai pemain dalam industri angkutan minyak, volume produksi dan konsumsi minyak dunia sangat mempengaruhi pertumbuhan permintaan jasa angkutan. Sementara itu, krisis ekonomi serta pergolakan di negara-negara Timur Tengah juga berakibat pada meningkatnya harga minyak dunia, sehingga konsekuensinya meningkatkan beban operasional BLTA. Kondisikondisi tersebut memiliki pengaruh yang merugikan bagi operasi perusahaan dan anak perusahaan sehingga menyebabkan penurunan gross profit dibandingkan tahun 2008.

Meskipun EBITDA masih positif namun pada tahun 2009 dan 2010 BLTA mengalami net loss terutama karena kerugian dari other expense akibat penurunan nilai (revaluasi) kapal, perubahan nilai wajar obligasi konversi dan wesel bayar serta peningkatan interest expense. 
Tabel 9 Resume Rasio Keuangan PT. BLTA TBK.

\begin{tabular}{|c|c|c|c|c|c|}
\hline & $\begin{array}{r}\text { Audited } \\
\text { 31-Dec-07 }\end{array}$ & $\begin{array}{r}\text { Audited } \\
\text { 31-Dec-08 }\end{array}$ & $\begin{array}{r}\text { Audited } \\
\text { 31-Dec-09 }\end{array}$ & $\begin{array}{r}\text { Audited } \\
\text { 31-Dec-10 }\end{array}$ & $\begin{array}{r}\text { Unaudited } \\
\text { 30-Jur-11 }\end{array}$ \\
\hline \multicolumn{6}{|l|}{ RATIOS : } \\
\hline \multicolumn{6}{|l|}{ Liquidity: } \\
\hline Current Ratio (\%) & $69.72 \%$ & $71.59 \%$ & $75.85 \%$ & $103.24 \%$ & $150.29 \%$ \\
\hline NWC (USD 000) & $(167,132)$ & $(128,627)$ & $(107,454)$ & 12,012 & 152,019 \\
\hline Quick Ratio (Acid Test Ratio) (\%) & $65.42 \%$ & $65.38 \%$ & $67.64 \%$ & $90.57 \%$ & $120.93 \%$ \\
\hline \multicolumn{6}{|l|}{ Profitability : } \\
\hline Gross Profit Margin (\%) & $45.16 \%$ & $45.97 \%$ & $43.09 \%$ & $36.54 \%$ & $37.17 \%$ \\
\hline Operating Profit Margin (\%) & $38.82 \%$ & $41.06 \%$ & $37.98 \%$ & $31.62 \%$ & $33.03 \%$ \\
\hline Net Profit Margin (\%) & $20.84 \%$ & $30.17 \%$ & $-46.23 \%$ & $-23.51 \%$ & $6.97 \%$ \\
\hline Return on Equity (ROE) (\%) & $22.89 \%$ & $39.43 \%$ & $-46.24 \%$ & $-22.57 \%$ & $6.19 \%$ \\
\hline Retum on Asset (ROA) (\%) & $3.67 \%$ & $9.51 \%$ & $-11.44 \%$ & $-5.45 \%$ & $1.50 \%$ \\
\hline \multicolumn{6}{|l|}{ Solvency: } \\
\hline Net Worth (USD 000) & 352,010 & 553,827 & 618,292 & 684,171 & 727,210 \\
\hline $\mathrm{DER}(\%)$ & $499.60 \%$ & $271.48 \%$ & $267.68 \%$ & $283.93 \%$ & $275.19 \%$ \\
\hline Leverage Ratio (\%) & $666.84 \%$ & $343.49 \%$ & $327.17 \%$ & $334.44 \%$ & $313.97 \%$ \\
\hline Interest Coverage Ratio (EBITDA to I) (\%) & $227.26 \%$ & $253.48 \%$ & $214.46 \%$ & $150.13 \%$ & $133.91 \%$ \\
\hline $\operatorname{DSCR}(\%)$ & & $97.99 \%$ & $78.95 \%$ & $65.49 \%$ & $34.37 \%$ \\
\hline \multicolumn{6}{|l|}{ Activity : } \\
\hline Sales per Month (USD 000) & 32,220 & 60,307 & 51,529 & 54,738 & 53,852 \\
\hline ARTO (hari) & 71 & 48 & 76 & 88 & 86 \\
\hline ITO (hari) & 21 & 12 & 16 & 14 & 26 \\
\hline APTO (hari) & 26 & 16 & 36 & 55 & 23 \\
\hline Asset Tum Over Ratio (\%) & $17.62 \%$ & $31.52 \%$ & $24.75 \%$ & $23.17 \%$ & $21.55 \%$ \\
\hline Net Trade Cycle (days) & 66 & 44 & 56 & 47 & 89 \\
\hline
\end{tabular}

Dari resume rasio keuangan, dapat diketahui bahwa secara umum likuiditas BLTA menunjukkan perbaikan yang mengindikasikan bahwa kemampuan perusahaan untuk melunasi hutang jangka pendeknya semakin baik. Pada tahun 2009 dan 2010, profitabilitas BLTA menurun yang disebabkan oleh penurunan pendapatan, kenaikan beban lain serta proses revaluasi aktiva tetap. Rasio solvabilitas meningkat. Peningkatan DER dan leverage mencerminkan bahwa BLTA semakin banyak menggunakan pembiayan yang bersumber dari interest bearing debt. Rasio aktivitas BLTA menunjukkan trend yang kurang baik dari tahun 2008 hingga 2010 karena adanya penurunan ARTO, ITO dan APTO.

Tabel 10 Resume Cashflow PT. BLTA TBK.

\begin{tabular}{|c|c|c|c|c|c|}
\hline & & & & & (USD 000) \\
\hline & $\begin{array}{r}\text { Audited } \\
\text { 31-Dec-07 }\end{array}$ & $\begin{array}{r}\text { Audited } \\
\text { 31-Dec-08 }\end{array}$ & $\begin{array}{r}\text { Audited } \\
\text { 31-Dec-09 }\end{array}$ & $\begin{array}{r}\text { Audited } \\
\text { 31-Dec-10 }\end{array}$ & $\begin{array}{r}\text { Unaudited } \\
\text { 30-Jun-11 }\end{array}$ \\
\hline SUMMARY OF STATEMENT OF CASH FLO & & & & & \\
\hline NetCash Flows From Operating Activities & N.A. & 402,147 & $(205,510)$ & $(40,090)$ & 11,094 \\
\hline NetCash Flows From Investing Activities & N.A. & $(228,234)$ & $(238,272)$ & $(476,287)$ & $(169,552)$ \\
\hline NetCash Flows From Financing Activities & N.A. & $(299,161)$ & 444,755 & 460,926 & 161,695 \\
\hline Net Increase (Decrease) In Cash & N.A. & $(125,248)$ & 973 & $(55,451)$ & 3,237 \\
\hline Cash to Income Ratio & & 1.35 & $(0.88)$ & $(0.19)$ & 0.10 \\
\hline Cash Flow to Revenue Ratio & & 0.56 & -0.33 & -0.06 & 0.03 \\
\hline
\end{tabular}

Dari resume cash flow, dapat diketahui bahwa kegiatan usaha BLTA ditopang oleh pendanaan yang berasal dari aktivitas pembiayaan baik yang berasal dari fasilitas bank dan lembaga keuangan dan penerbitan obligasi serta hutang dengan perusahaan afiliasi. BLTA mengalami penurunan pendapatan pada tahun 2009 yang berdampak signifikan kepada kemampuan BLTA untuk 
menghasilkan kas operasi sehingga pada tahun 2009 belum mampu menghasilkan kas operasi, atau mengalami penurunan dari tahun 2008 yang mampu menghasilkan kas operasi sebesar USD 402.15 juta.

\section{Perkembangan Harga Saham BLTA di BEI}

BLTA menawarkan sahamnya untuk pertama kali sebannyak 2.100.000 lembar saham seharga Rp. 8.500/lembar yang disetujui oleh Menteri keuangan RI dengan Surat Keputusan No. S1076/SHM/MK.01/1990 tanggal 22 Januari 1990. Saham-saham tersebut telah dicatat di BEI pada tanggal 26 Maret 1990. Trend perkembangan harga saham BLTA di BEI sejak tanggal 2 Januari 2008 sampai dengan tanggal 23 Juli 2012 adalah sebagai berikut.

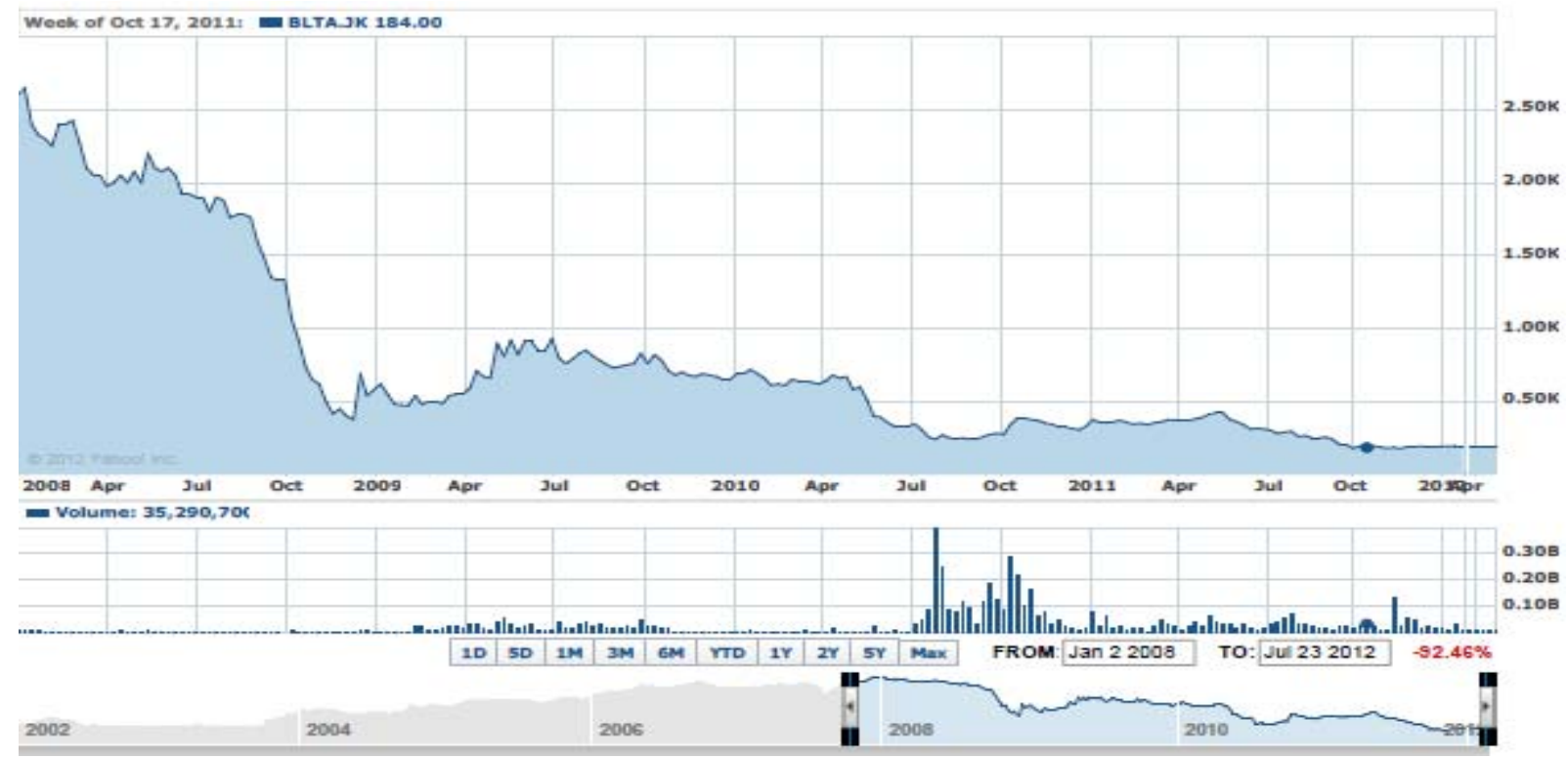

Gambar 1 Tren Perkembangan Harga Saham PT. BLTA TBK.

Harga pasar saham BLTA di BEI turun dari Rp 2.600/lembar pada akhir tahun 2007 menjadi sebesar Rp. 196/lembar pada penutupan perdagangan tanggal 16 Agustus 2012. Tren penurunan tersebut tentunya disebabkan oleh penurunan kinerja keuangan BLTA serta reaksi investor atas kinerja tersebut.

\section{Evaluasi Z Score atas Kinerja Keuangan BLTA}

Berdasarkan data laporan keuangan audit tahun 2007 sampai dengan 2010 dan laporan keuangan inhouse per Juni 2011 dengan menggunakan analisis Z Score Model, maka diperoleh hasil sebagai berikut. 
Tabel 11 Laporan Keuangan PT. BLTA TBK. dengan Altman Score Model

\begin{tabular}{|c|c|c|c|c|c|}
\hline \multirow[b]{2}{*}{ Z Score Ratio Components } & \multirow[b]{2}{*}{ 31-Dec-07 } & \multirow[b]{2}{*}{ 31-Dec-08 } & \multirow[b]{2}{*}{ 31-Dec-09 } & \multicolumn{2}{|c|}{ (USDOUO) } \\
\hline & & & & 31-Dec-10 & 30-Jun-11 \\
\hline Working Capital & $(167,132)$ & $(128,627)$ & $(107,454)$ & 12,012 & 152,019 \\
\hline Total Assets & $2,194,354$ & $2,295,926$ & $2,497,922$ & $2,835,511$ & $2,998,403$ \\
\hline Retained Earnings & 332,318 & 530,921 & 297,554 & 164,156 & 207,195 \\
\hline Earnings Before Interest and Taxes & 147,585 & 336,611 & $(175,415)$ & $(14,894)$ & 103,014 \\
\hline Total Liabilities & $1,842,345$ & $1,742,099$ & $1,879,630$ & $2,151,340$ & $2,159,284$ \\
\hline Net Worth & 352,010 & 553,827 & 618,292 & 684,171 & 727,210 \\
\hline Sales & 386,641 & 723,682 & 618,346 & 656,854 & 323,111 \\
\hline Z Score Ratio & 31-Dec-07 & 31-Dec-08 & 31-Dec-09 & 31-Dec-10 & 30-Jun-11 \\
\hline X1, Working Capital/Total Assets & (0.070) & $(0.050)$ & $(0.043)$ & 0.004 & 0.051 \\
\hline X2, Retained Earnings/Total Assets & 0.151 & 0.231 & 0.119 & 0.058 & 0.069 \\
\hline $\mathrm{X}$, Earnings Before Interest and Taxes/Total Assets & 0.067 & 0.147 & $(0.070)$ & $(0.005)$ & 0.034 \\
\hline X4, Market Value of Equity/Book Value of Total Liabilities & 0.623 & 0.140 & 0.219 & 0.197 & 0.175 \\
\hline $\mathrm{X}$, Sales/Total Assets & 0.176 & 0.315 & 0.248 & 0.232 & 0.108 \\
\hline
\end{tabular}

\begin{tabular}{|c|c|c|c|c|c|}
\hline Z Score Ratio & 31-Dec-07 & 31-Dec-08 & 31-Dec-09 & 31-Dec-10 & 30-Jun--11 \\
\hline Z Score & \multicolumn{5}{|c|}{$1,2 \mathrm{X} 1+1,4 \mathrm{X} 2+3,3 \mathrm{X} 3+0,6 \mathrm{X} 4+1,0 \mathrm{X} 5$} \\
\hline \multirow[t]{2}{*}{ Z Score } & 0,893 & 1,139 & 0,263 & 0,418 & 0,483 \\
\hline & Bankruptcy & Bankruptcy & Bankruptcy & Bankruptcy & Bankruptcy \\
\hline Z Score & \multicolumn{5}{|c|}{$0,717 \times 1+0,847 \times 2+3,107 \times 3+0,420 \times 4+0,998 \times 5$} \\
\hline \multirow[t]{2}{*}{ Z' Score } & 0,720 & 0,984 & 0,191 & 0,350 & 0,382 \\
\hline & Bankruptcy & Bankruptcy & Bankruptcy & Bankruptcy & Bankruptcy \\
\hline Z" Score & \multicolumn{5}{|c|}{$6,56 \mathrm{X} 1+3,26 \times 2+6,72 \times 3+1,05 \times 4$} \\
\hline \multirow[t]{2}{*}{ Z" Score } & 1,100 & 1,518 & $-0,136$ & 0,388 & 0,972 \\
\hline & Gray Area & Gray Area & Bankruptcy & Bankruptcy & Bankruptcy \\
\hline
\end{tabular}

Berdasarkan evaluasi dengan menggunakan Z Score tersebut di atas, diketahui bahwa dengan menggunakan model Z Score awal (Z) dan Z' sejak tahun 2007 atau 5 (lima) tahun sebelum BLTA mengumumkan default pembayaran hutang, nilai Z Score sudah diklasifikasi bankruptcy dan klasifikasi tersebut terjadi terus menerus sampai dengan Juni 2011. Hal ini sesuai dengan penelitian Altman bahwa potensi kebangkrutan sudah terlihat sejak 5 (lima) tahun sebelum perusahaan bangkrut atau menyatakan default.

Apabila menggunakan Z’' score, tahun kelima dan keempat ternyata masih klasifikasi gray area, namun tiga tahun terakhir diklasifikasikan bangkrut. Secara umum dapat disimpulkan bahwa evaluasi menggunakan Z Score, Z' Score dan Z'' Score, potensi kebangkrutan BLTA telah dapat diprediksi sejak 5 (lima) tahun sebelum BLTA mengumumkan bahwa mereka tidak mampu memenuhi kewajiban keuangannya baik kepada lembaga keuangan maupun kepada pemegang obligasi.

Apabila dikaitkan dengan komponen rasio Z Score, trend working capital yang negatif, retained earning yang menurun, EBIT yang menurun/negatif, dan peningkatan total liabilities serta penurunan sales sangat mempengaruhi nilai Z Score. Hal tersebut disebabkan oleh kondisi krisis ekonomi yang membebani industri angkutan kapal laut serta kebijakan manajemen BLTA yang membiayai kegiatan operasi dan investasi menggunakan hutang bank/lembaga keuangan dan penerbitan obligasi yang belum mampu mendorong peningkatan pendapatan perusahaan. 


\section{PENUTUP}

Krisis ekonomi menyebabkan BLTA mengalami penurunan pendapatan. Berdasarkan analisis cash flow diketahui bahwa biaya operasional dan investasi BLTA dibiayai dari hutang. Kondisi tersebut ditambah dengan proses revaluasi aset menyebabkan BLTA mengalami penurunan pendapatan dan net loss. Kesulitan likuiditas yang dicerminkan oleh cash to income ratio yang rendah menyebabkan BLTA tidak dapat memenuhi kewajiban keuangannya (default). Berdasarkan evaluasi menggunakan Altman's Z Score (Z, Z', Z”) diketahui bahwa sejak tahun 2007 nilai yang dihasilkan berada dalam kategori bangkrut dan nilai tersebut terus berlanjut sampai dengan laporan keuangan Juni 2011. Dengan demikian dapat disimpulkan bahwa dengan menggunakan Altman's Z Score dapat secara dini memprediksi potensi kebangkrutan BLTA. Sangat disarankan apabila investor saham dan obligasi secara berkala melakukan analisis Z Score atas laporan keuangan emiten sehingga potensi kerugian investor dapat diminimalisasi.

\section{DAFTAR PUSTAKA}

Altman, E. I. (1993). Corporate Financial Distress and Bankruptcy. second edition. New York: John Wiley \& Sons.

Brigham, E. F. (2002). Intermediate Financial Mangement, (seventh edition). South Western Publishing, Forth Worth.

http://www.pefindo.com

Kieso, D. E., Weygandt, J. J., Warfield, T. D. (2011). Intermediate Accounting IFRS Edition Volume 1. New York: John Wiley \& Sons.

White, G. I., Sondhi, A. C., Fried, D. (2003). The Analysis and Use of Financial Statements. third edition. New York: John Wiley \& Sons.

www.blt.co.id

www.idx.co.id 